\title{
Analisis Data Penjualan Perusahaan Detergen XYZ dengan Aplikasi Zoho Reporting Menggunakan Metode OLAP (Online Analytical Processing)
}

\author{
Ricky Akbar" ${ }^{\# 1}$, Elsha Yuliani" ${ }^{\#}$ Qisty Mawaddah ${ }^{\# 2}$ dan Fikri Ardhana ${ }^{\#}$ \\ \#Jurusan Sistem Informasi Fakultas Teknologi Informasi Universitas Andalas \\ Jln.Limau Manis, Pauh 25163, Padang, Sumatera Barat \\ ${ }^{1}$ rickyakbar1984@gmail.com \\ ${ }^{2}$ mawaddahqisthy@gmail.com
}

\begin{abstract}
Abstrak - Sales Channel atau saluran penjualan merupakan salah satu hal yang harus diperhatikan oleh perusahaan. Sales channel yang beragam memungkin perusahaan untuk memperbesar keuntungan mereka, sales channel online misalnya dengan sales channel ini perusahaan dapat memperluas lokasi pemasaran keseluruh negara-negara di dunia. Perusahaan yang memiliki sales channel yang banyak dan memproduksi barang yang biasa digunakan sehari-hari, memiliki data pelanggan yang sangat besar diberbagai belahan dunia. Prediksi jumlah penjualan produk di masingmasing negara berdasarkan sales channel yang digunkan perusahaan merupakan Business Intelligence (BI) yang sangat penting untuk melihat negara mana yang berpotensi memberikan pelanggan yang besar untuk penjualan produk perusahaan. Dari penelitian dengan menggunakan metode OLAP (Online Analytical Processing) dan aplikasi Zoho Reporting, dapat membantu pihak pengambil keputusan dalam menemukan pelanggan dari negara mana yang nantinya berpotensi memberikan keuntungan besar bagi perusahaan.
\end{abstract}

Kata kunci- business intelligence, online analytical processing, sales channel, prediksi.

\section{PENDAHULUAN}

Teknologi saat ini semakin berkembang dari tahun ke tahun. Banyak inovasi - inovasi yang mendasari perkembangan teknologi semakin maju. Seiring perkembangan teknologi , banyak adanya kegiatan bisnis yang bisa dilakukan dengan mudah tanpa harus memikirkan tempat, dana dan waktu. Kegiatan bisnis dengan memanfaatkan teknologi bisa saja dilakukan di dalam rumah. Oleh karena itu, semakin banyak persaingan kegiatan bisnis dengan adanya perkembangan teknologi yang semakin maju, terutama dalam penerapannya dengan teknologi informasi. Pengimplementasian teknologi informasi dalam kegiatan bisnis dapat memepermudah kita dalam melakukan kegiatan bisnis.
Dengan adanya teknologi informasi, pada perusahaan yang memiliki kegiatan bisnis nantinya akan berpotensi besar dalam menghasilkan data yang melimpah. Data perusahaan yang melimpah menyebabkan proses pengambilan informasi menjadi lambat.

Hal ini menjadi tantangan bagi perusahaan untuk dapat mengelola data serta mengambil informasi secara cepat dan efisien. Data yang melimpah akan menjadi tidak berguna apabila tidak ada pengelolaan yang baik dan juga analisa terhadap aktifitas bisnis. Dengan adanya informasi, perusahaan dapat meningkatkan kinerjanya dalam pengambilan keputusan yang akurat dengan resiko yang seminimal mungkin untuk dapat memaksimalkan keuntungan dan kemajuan perusahaan.

Kecepatan dalam pengolahan data sangat dibutuhkan dengan adanya data yang sangat banyak. Pengolahan data yang akurat serta dapat nantinya memberikan informasi yang berguna bagi kegiatan bisnis perusahaan dapat dibantu dengan penerapan kecerdasan bisnis didalamnya. Kemampuan Bussiness Inteligence dapat membantu dalam melakukan analisis data, analisis historical data dan membantu dalam pengambilan keputusan dari informasi yang didapat dari pengolahan data. Dengan pengimplementasian business intelligence perusahaan juga dapat mengamati analisis data penjualan yang paling diminati oleh masyarakat.

Pengaplikasian business intelligence itu sendiri, bisa dilakukan dengan memanfaatkan aplikasi open source yang menerapkan sistem kecerdasan bisnis. Sangat sedikit dari para pebisnis melakukan analisis data secara online, karena memang keamanan data sangat memberikan dampak tidak adanya keamanan data jika diolah secara online. Namun, Zoho reports merupakan aplikasi business intelligence yang dapat menjaga keamanan data dengan adanya sistem database yang bisa menjadi perantara ke sistem database terpusat. Zoho reports juga mampu mengolah data dalam jumlah besar. Melalui metode Online Analitycal Processing (OLAP), Zoho Reports tentunya 
merupakan aplikasi yang mampu mengolah data secara online , tanpa memakan kapasitas memori yang besar.

Terkait metode penelitian yang telah dilakukan oleh beberapa peneliti, seperti penelitian dari Giat Karyono mengenai pengembangan data warehouse dan OLAP untuk penemuan informasi dan analisis data, implementasi penelitian yang digunakan oleh Giat karyono terhadap aplikasi OLAP PMB dengan operasi Roll-up, Drill-down, Slice, Dice, Pivot, dan Grafik.

Penelitan yang dilakukan oleh Hengky Saputra mengenai Pembangunan Data Warehouse Pada Institusi Pengkajian Teknologi Pertanian Jawa Barat, memakai metode OLAP dengan menggunakan operasi Roll-up, Drill-down, Slice, Dice dan Pivot dan tidak menggunakan operasi grafik. Selanjutnya penelitian yang dilakukan oleh I Dewa Made Adi Baskara Joni yaitu Penerapan OLAP Untuk Monitoring Kinerja Perusahaan, memakai metode OLAP dengan menggunakan operasi Slicing, Dicing, Drill-up dan Drill-down, serta Pivot.

Kegiatan pengumpulan data dapat dilakukan dengan menagambil dari database perusahaan yang digunakan sebagai obyek penerapan BI. Data yang kami gunakan dalam analisis ini adalah data online dari perusahaan detergen XYZ, data ini diolah menggunakan Aplikasi Zoho Reports untuk dilihat pada Negara mana terdapat penjualan terbesar berdasarkan masing-masing sales channel yaitu, sales channel online, sales channel direct, dan sales channel retail.

\section{DASAR-DASAR TEORI}

\section{A. OLAP}

Online Analytical Processing (OLAP) adalah sebuah pendekatan secara cepat untuk memudahkan analisis multidimensi. OLAP merupakan bagian dari Business Intelligence yang memiliki kaitan erat dengan relational database, reporting dan data mining. OLAP memiliki beberapa operasi untuk menganalisa data multidimesi.[1]

Online Analytical Processing (OLAP) merupakan teknologi yang memungkinkan analis, manajer dan eksekutif secara bersamaan mengakses data secara cepat, konsisten dan interaktif dengan berbagai variasi tinjauan informasi dimana setiap baris data dapat ditransformasikan untuk merefleksikan dimensi perusahaan sehingga mudah dipahami oleh user". Karakteristik utama dari OLAP, meliputi:

1. Mendukung pemanfaatan data warehouse yang memiliki data multidimensional.

2. Menyediakan fasilitas query interaktif dan analisis yang kompleks.

3. Menyediakan fasilitas drill-down untuk memperoleh informasi yang rinci, dan roll-up untuk memperoleh agregat dalam multidimensi.

4. Mampu menghasilkan perhitungan dan perbandingan.

5. Menyajikan hasil dalam angka yang mudah dimengerti, maupun penyajian grafik.[3]

Operasi-operasi yang terdapat pada OLAP antara lain:

- Slicing dan Dicing
Merupakan operasi untuk melihat data sebagai visualisasi dari kubus. Dengan slicing dan dicing pengguna dapat melihat data dari beberapa perspektif atau dimensi. Pengguna dapat mengekstrak bagian dari data agregated dan dapat memeriksa dengan detail berdasarkan dimensi-dimensi yang diinginkan (Kember, 2006).[4]

- Roll up dan drill down

Merupakan operasi untuk melihat data global atau detail disepanjang level hirarki dimensi. Roll up untuk melihat data secara global atau rangkuman (summary). Drill down memandu pengguna untuk memperoleh data yang lebih detail (Kamber, 2006).[4]

\section{B. Business Intelligence}

"Business Intelligence (BI) adalah seperangkat teori, metodologi, proses, arsitektur, dan teknologi yang mengubah data mentah menjadi informasi yang bermakna dan berguna untuk tujuan bisnis. BI dapat menangani sejumlah besar informasi untuk membantu mengidentifikasi dan mengembangkan peluang baru. Memanfaatkan peluang baru dan menerapkan strategi yang efektif dapat memberikan keuntungan pasar kompetitif dan stabilitas jangka panjang.[1]

Business Intelligence (Intelejen Bisnis) adalah suatu cara untuk mengumpulkan, menyimpan, mengorganisasikan, membentuk ulang, meringkas data serta menyediakan informasi, baik berupa data aktifitas bisnis internal perusahaan, maupun data aktifitas bisnis eksternal perusahaan termasuk aktifitas bisnis para pesaing yang mudah diakses serta dianalisis untuk berbagai kegiatan manajemen (Edward David ,2000).[2]

Berdasarkan definisi diatas bahwa fungsi Business Intelligence adalah sebagai sistem pendukung pengambilan keputusan dimana sistem dan aplikasi ini mengubah datadata dalam suatu perusahaan atau organisasi (data operasional, data transaksional, atau data lainnya) ke dalam bentuk pengetahuan.[2]

Struktur Tim Proyek BI pada umumnya adalah sebagai berikut :

- Tim Inti

Adalah tim yang mampu mengorganisir dirinya sendiri, membagi beban kerja, saling koreksi, membuat keputusan bersama, bertukar pikiran dan memimpin proyek.

- Tim Pendukung

Anggota tim ini bertanggung jawab terhadap pengembangan BI tetapi bagi mereka proyek BI bukan prioritasnya. Mereka dipanggil jika keahliannya dibutuhkan untuk memecahkan masalah atau untuk membuat keputusan.[5]

Hal lain yang perlu diperhatikan dalam dalam pengembangan proyek BI adalah :

- Pemilik data adalah sebagian besar pemegang saham. Mereka mempunyai tanggung jawab terhadap kwalitas bisnis dan validitas metadata bisnis

- Fasilitator adalah pihak ke tiga yang berpartisipasi 
selama peninjauan penerapan. Merekalah yang memimpin pertemuan selama melakukan peninjauan

- Penulis juga dapat dilibatkan sebagai seorang yang bertugas membuat dokumentasi selama pertemuan dan mencatat aksi yang harus dilakukan setelah peninjauan.[5]

\section{Zoho Reports}

Zoho adalah penyedia aplikasi secara online. Di dalam zoho ada berbagai macam aplikasi yang bisa kita manfaatkan secara online. Dari sosial network, blog, pembuatan dokumen, presentation, spreadsheet dll . Dengan beragam informasi aplikasi online yang ditawarkan, pantaslah kalau Zoho disebut kantor berjalan. Selain 3 aplikasi kantoran standart, zoho juga menyediakan berbagai aplikasi pendukung produktivitas, kolaborasi dan bisnis. Namun tak semua gratis, terutama produk yang ada di jajaran aplikasi bisnis.

Zoho Business intelligence program yaitu zoho report menawarkan versi gratis dengan penambahan bonus dua user. Ekstra users bisa ditambahkan jika kita membayarkan harga $\$ 10 /$ bulan. Versi gratis ini juga menyediakan reports dan dashboard yang tidak terbatas, seperti layaknya cloud storage. Tidak ada batasan dari ukuran file ada Zoho cloud storage, tapi ada batasan untuk jumlah dari baris reports.[6]

\section{III.HASIL DAN PEMBAHASAN}

Sesuai dengan permasalahan yang diangkat dalam penelitian ini, data yang digunakan dalam melakukan analisis data adalah data penjualan perusahaan detergen XYZ di seluruh negara. Terdapat 3 pemabagian sales channel yaitu secara direct, retail dan online.

Sales Channel Direct merupakan penjualan produk langsung dari pabrik. Sales Channel Online merupakan penjualan produk yang di pesan ke pabrik secara online berdasarkan jumlah produk yang akan dikirim. Sales Channel Retail merupakan penjualan produk dari pabrik melalui perantara.

Perbandingan data analisis pada penjualan detergen melalui sales channel dilihat dari jumlah unit yang terjual dan di negara mana produk produk tersebut terjual.

Pembuatan data analisis menggunakan aplikasi zoho reports dengan metode online dapat diolah secara akurat. Sebelum data tersebut diolah pada tahap pertama, data di filter berdasarkan kategori sales channel, berikut adalah data hasil filter berdasarkan sales channel dapat dilihat pada Gambar 1.

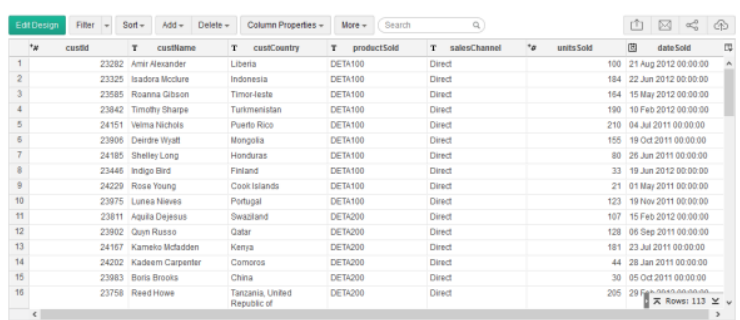

Gambar 1. Data filter berdasarkan sales channel Direct

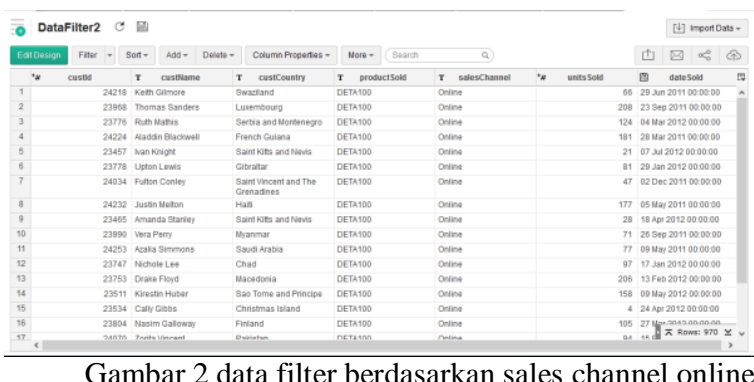

Gambar 2. Menunjukkan data hasil filter berdasarkan sales chanel online. Dari gambar diatas hanya data dengan penjualan online saja yang dapat dilihat oleh pengguna zoho reports.

Selanjutnya data dapat difilter lagi dengan jenis data penjualan retail, dapat dilihat pada Gambar 3. Yaitu data hasil filter terhadap penjualan retail. Pengguna hanya bisa melihat jenis data penjualan retail saja.

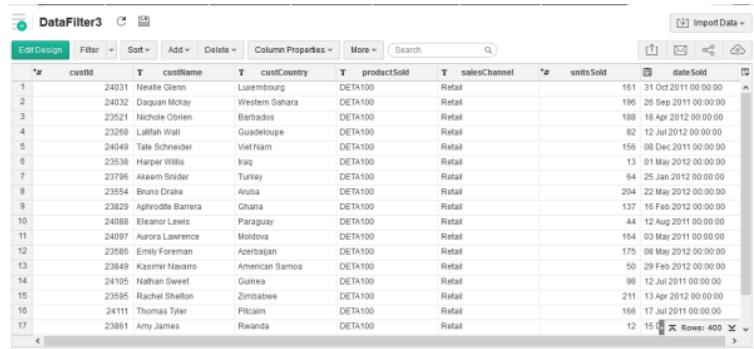

Gambar 3. Data filter berdasarkan sales channel retail

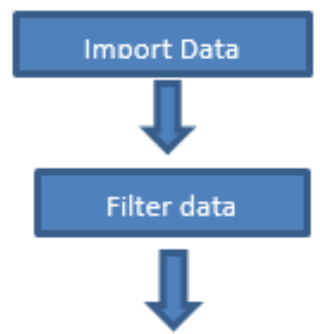

Pembuatan Chart grafik dan OLAP Report

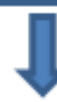

Hasil report

Gambar 4 Metode Pemrosesan data

Gambar 4 merupakan metode pemrosesan data pada aplikasi zoho reports. Berikut adalah langkah - langkah yang dapat dilakukan oleh zoho resports dalam melakukan proses data.

1. Import Data

Data terlebih dahulu di import pada aplikasi zoho reports dengan cara "Import New Table".

2. Lakukan filter data dengan pengelompokkan kriteria sales channel.

3. Pembuatan Chart grafik dan OLAP Report. 
Proses ini dilakukan dengan memisahkan filter dari ketiga data, lalu melakukan pembuatan grafik berupa chart perbandingan penjualan detergen di seluruh negara.

Operasi yang dilakukan tentang metode OLAP pada penelitian ini yaitu :

a. Coonsolidation (roll-up)

Konsolidasi melibatkan pengelompokkan data untuk melihat data secara global atau rangkuman dari ketiga data yang akan dianalisis.

\section{b. Drill - Up dan Drill Down}

Menavigasi antara tingkat data mulai dari yang paling diringkas (atas) ke yang paling rinci (bawah).

Lalu data yang telah dijadikan grafik chart baru dijadikan OLAP report merupakan report pertumbuhan bisnis perusahaan detergen.

Berikut adalah grafik chart dari data penjualan dapat dilihat pada Gambar 5. Grafik pada gambar 5. Menjelaskan grafik penjualan pada sales channel Direct. Pada sales channel Direct didaptkan penjualan tertinggi pada daerah Turkey, dengan total unit yang terjual sebanyak 516 unit.

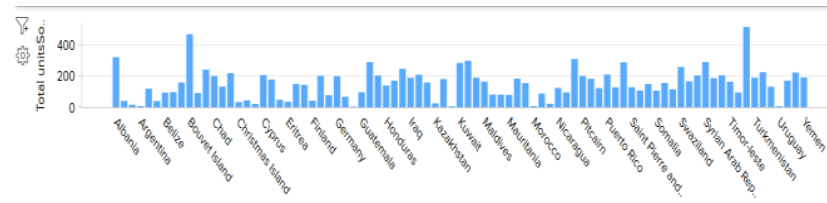

Gambar 5 Analisis Data penjualan Direct

Salah satu data penjualan tertinggi ada pada sales direct pada Negara Turkey dapat dilihat pada Gambar 6 .

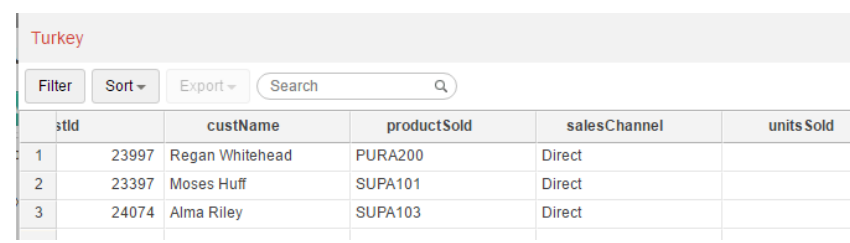

Gambar 6. OLAP Report dari Sales Chanel Direct

Analisis Penjualan detergen dengan sales channel Online yang digambarkan dengan grafik dapat dilihat pada Gambar 7. Sangat banyak Negara yang melakukan penjualan online, jika dibandingkan grafiknya dengan penjualan direct dan retail. pada sales channel online data penjualan tertinggi didapatkan pada negara Pakistan dengan total penjualan sebanyak 1942 unit.

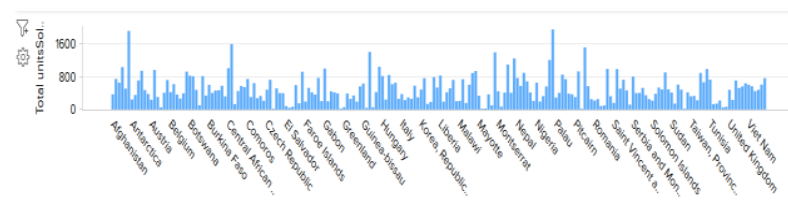

Gambar 7 analisis Data penjualan Online

Gambar 8. Merupakan laporan penjualan Online. Salah satu negara dengan penjualan tertinggi yaitu pakistan.

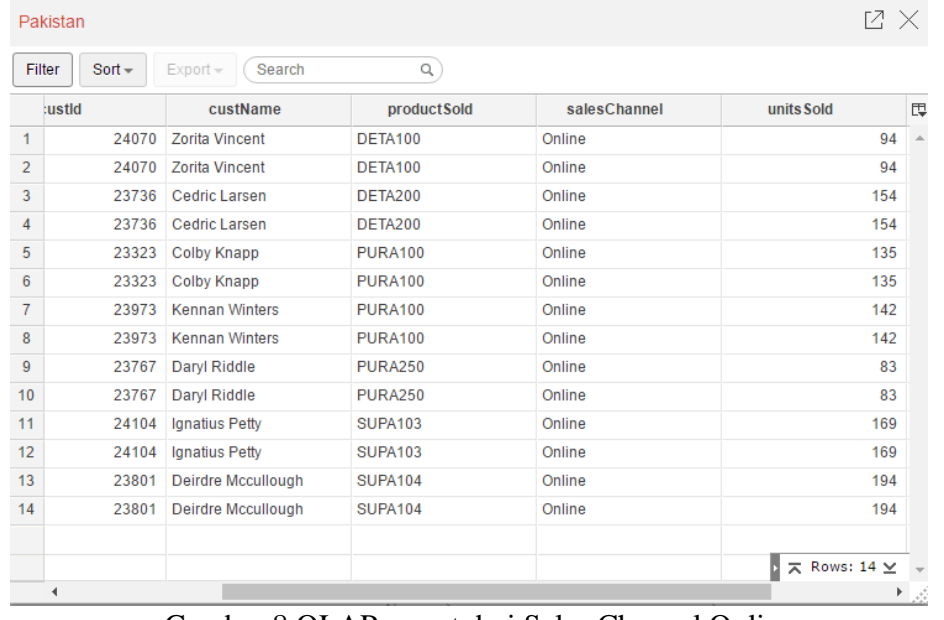

Gambar 8 OLAP report dari Sales Channel Online

Analisis penjualan retail hampir sama banyaknya dengan analisis penjualan online, dapat dilihat pada gambar 9. Dapat dilihat dengan penggambaran grafik penjualan dengan sales channel Retail. Penjualan tertinggi didapatkan pada negara Iceland dengan total penjualan sebanyak 731 unit.

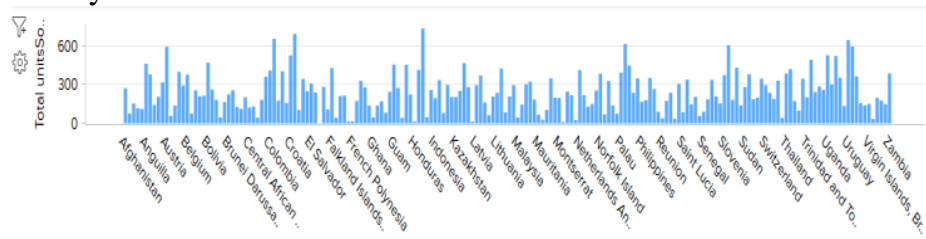

Gambar 9 analisis Data Penjualan Retail

Berikut adalah laporan penjualan pada salah satu Negara yang melakukan penjualan detergen secara retail. Dapat dilihat pada gambar 10.

\begin{tabular}{|c|c|c|c|c|c|c|}
\hline \multicolumn{5}{|c|}{ Iceland } & \multicolumn{2}{|c|}{$[\pi \times$} \\
\hline Filter & Sort - & Export - Search & a & & & \\
\hline \multicolumn{2}{|c|}{ ustld } & custName & productSold & salesChannel & units Sold & 因 \\
\hline 1 & 23688 & Jessamine Watkins & DETA800 & Retail & 161 & - \\
\hline 2 & 23721 & Montana Vincent & PURA250 & Retail & 194 & \\
\hline 3 & 24247 & Forrest Maddox & PURA250 & Retail & 74 & \\
\hline 4 & 24008 & Devin Shepard & PURA250 & Retail & 139 & \\
\hline 5 & 23348 & Tad Mack & SUPA104 & Retail & 163 & \\
\hline
\end{tabular}

Gambar 10 OLAP report dari Sales Channel Retail

Dari tahapan pemrosesan data yang dilakukan didapatkan hasil penjualan produk tertinggi terdapat pada negara Puerto Rico, dan penjualan produk lebih banyak melalui slaes Channel online. Dan penjualan terendah didapatkan pada negara Mexico yang hanya terjual 2 unit.

Berikut adalah Chart penjualan produk secara keseluruhan dapat dilihat pada Gambar 11. Hasil penjualan > 1600.

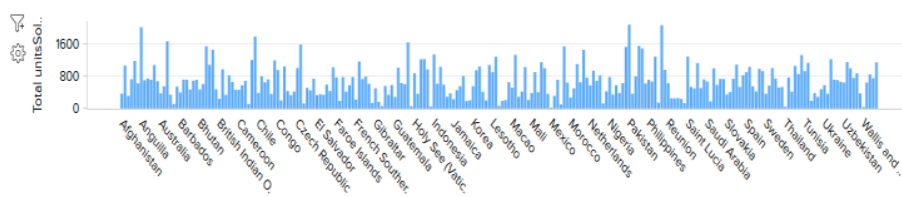

Gambar 11 Grafik keseluruhan penjualan unit. 


\section{KESIMPULAN}

Berdasarkan analisis data penjualan yang telah dilakukan dapat disimpulkan, bisnis Penjualan dari perusahaan detergen XYZ tampak jelas, bahwa banyak dilakukan secara online. Dapat dilihat Online Report dari data penjualan online adalah paling padat chart grafiknya.

Dengan menggunakan metode OLAP, data bisa diolah secara online. Zoho reports adalah aplikasi yang mendukung dalam penganalisisan data secara online.

\section{REFERENSI}

[1] Zaky Nur Husni, Imam Mukhlash. "Implementasi Business Intelligence Pada Manajemen Report Bank XYZ”. Jurnal Sains Dan Senni Pomits. 2014

[2] Imelda. "Business Intelligence". Majalah Ilmiah UNIKOM. Vol.11 No.1

[3] Ashar Johar, Arie Vatresia, Lia Martasari. “Aplikasi Business Intelligence (BI) Data Pasien Rumah Sakit M. Yunus Bengkulu dengan Menggunakan Metode OLAP (Online Analytical Processing)”. Jurnal Rekursif, Vol. 3 No.1. Maret 2015

[4] Lita Alfriany Ndoloe. "Sistem Informasi Lulusan Dengan Metode Online Analitycal processing (OLAP) Pada Politeknik Negeri Kupang”. Jurnal Sistem Informasi Bisnis. 2012

[5] Heribertus Himawan. "Implementasi Sistem Business Intelligence Untuk Melakukan Analisis Data Guna Mendukung Pembuatan Keputusan Manajer”. Techno.com Vol. 7 No.1. Mei 2008

[6] http://ilmukomputer.org/wp-content/uploads/2013/06/adibazoho.doc 